\title{
Larval chaetotaxy and morphometry of Oosternum costatum (Coleoptera: Hydrophilidae) including a discussion of larval characters with phylogenetic relevance
}

\author{
Miguel ARCHANGELSKY
}

Laboratorio de Investigaciones en Ecología y Sistemática Animal(LIESA). Centro de Investigaciones Esquel de Montaña y Estepa Patagónica (CIEMEP) (CONICET - UNPSJB), Roca 780, 9200 Esquel, Chubut, Argentina; e-mail: hydrophilinae@gmail.com



$14^{\text {th }}$ November 2018

\begin{abstract}
The primary and secondary chaetotaxy of the head capsule and head appendages of the first and third larval instars of Oosternum costatum (LeConte, 1855) (Coleoptera: Hydrophilidae: Sphaeridiinae, Megasternini) are described for the first time. Morphometric characters derived from the head capsule and mouthparts are included, together with detailed illustrations of all characters. The morphology and chaetotaxy of these larvae is compared to that of other larvae of the tribe Megasternini, confirming that chaetotaxy is a useful source of characters for phylogenetic analyses. Comparative notes with Sphaeridium Fabricius, 1775 (Sphaeridiini) are also included.
\end{abstract}

Key words. Coleoptera, Hydrophilidae, Sphaeridiinae, Megasternini, Oosternum, water scavenger beetles, larva, head, chaetotaxy, morphology, phylogeny

Zoobank: http://zoobank.org/urn:1sid:zoobank.org:pub:5619DD9C-DA43-4705-8C61-13883B600CE3

(C) 2018 The Authors. This work is licensed under the Creative Commons Attribution-NonCommercial-NoDerivs 3.0 Licence.

\section{Introduction}

Water scavenger beetles are well known for their aquatic representatives, nevertheless, most species included within the subfamily Sphaeridiinae are typically terrestrial (SHORT \& FIKÁČEK 2011, 2013; BLOOM et al. 2014). The knowledge of preimaginal forms of Sphaeridiinae is poor especially when compared to the data available for aquatic members of Hydrophilidae. It is sufficient to mention that Megasternini, one of the most diverse tribes within Sphaeridiinae (including 50 current valid genera, SHORT \& FIKÁČEK 2013), has larval descriptions available for only seven of those genera: Armostus Sharp, 1890, Cercyon Leach, 1817, Cryptopleurum Mulsant, 1844, Megasternum Mulsant, 1844, Motonerus Hansen, 1989, Oosternum Sharp, 1882, and Pelosoma Mulsant, 1844 (Phillips 1923; BöVING \& Henriksen 1938; Hafez 1939; Quennedey 1965; Prins 1984; Schulte 1985; Archangelsky 1997, 2016; FuhrMANN et al. 2013; MinOSHIMA in press; Fikáček unpubl. data). The only genera for which chaetotaxic descriptions have been published are Armostus and Cercyon, for all the other genera only morphological descriptions are available
(FIKÁČEK 2006; ARCHANGELSKY 2016; MinOSHIMA in press).

Oosternum is a genus of minute beetles, including 35 described species (Short \& FiKÁčEK 2011; Deler-HerNÁNDEZ et al. 2014), and many more await description (e.g. Deler-Hernández et al. 2014). These beetles live in a variety of habitats such as leaf-litter, dung and rotting animal carcasses with adults collected via Berlese funnels, flight intercept traps, and also with dung traps mixed with fermenting malt (SMETANA 1978; ArCHANGELSKY 1997; DeLER-HERnÁndEZ et al. 2014). Developmental information for Oosternum costatum (LeConte, 1855) was published by Archangelsky (1997).

The only species for which the preimaginal stages are known is Oosternum costatum (ARCHANGELSKY 1997, described as Pemelus costatus), for which the general morphology of the egg case, third instar larva and pupa were described. This emphasizes the poor knowledge we have of this genus and of this tribe of beetles.

With the aim of improving knowledge of preimaginal Megasternini, this paper describes the larval chaetotaxy and morphometry of Oosternum costatum; for general 
morphological characters ARCHANGELSKy (1997) should be consulted. Comparative notes with other Megasternini and Sphaeridiini larvae are included, together with the discussion of some relevant characters with phylogenetic significance.

\section{Material and methods}

Comparative material. For comparison, larvae of other sphaeridiine genera were examined:

Cercyon praetextatus (Say, 1825) 7 L1, 3 L2, 6 L3 (M. Archangelsky research collection): USA: Оніо: Holmes Co., 21.vii.1990, Killbuck Creek, near Killbuck (P. W. Kovarik, S. Wells, M. Archangelsky leg.).

Cercyon quisquilius (Linnaeus, 1761) 6 L1, 4 L2, 6 L3 (M. A. research collection): ARGENTINA: Chubut: Aldea Escolar, ex horse manure, 28.ii.2015 (M. Archangelsky leg.).

Cryptopleurum minutum (Fabricius, 1775) 1 L1, 2 L3 (M. A. research collection): USA: Oніо: Fayette Co., ex donkey and horse manure, v-vi.1995 (B. Gerdeman leg.).

Pelosoma sp. 3 L1, 2 L3 (M. A. research collection): VENEZUELA: Aragua: H. Pittier National Park, Rancho Grande Biological Station: La Toma trail $1100 \mathrm{~m}$, and La Trilla cacao plantation 300-400 m (ex Heliconia flowers), 4-21.viii.1994 (M. Archangelsky leg.);

Sphaeridium spp. 3 L2 or L3 (M. A. research collection). USA: Оніо: Lancaster Co., ex horse and cow manure, 19.vi.1994 (D.L. Wrensch leg.). USA: OHIO: Fayette Co., ex donkey and horse manure, vi.1995 (B. Gerdeman leg.).

Information on larvae of Armostus ohyamatensis Hoshina \& Satô, 2006 and Motonerus obscurus Hansen, 1989 was kindly provided by Dr. Y. Minoshima (Minoshima in press), and Dr. M. Fikáček (unpubl. data).

Methods. Oosternum costatum adults were reared in laboratory, where the complete life cycle was obtained. Rearing techniques follow those of ARCHANGELSKY (1997). Larvae were killed in boiling water and preserved in $75 \%$ ethyl alcohol. They were cleared in warm lactic acid, dissected and mounted on glass slides with Hoyer's medium. Observations (up to $1000 \times$ ) and drawings were made using a Leica S6D dissecting microscope and a Leica DMLB compound microscope, both with camera lucida and a photographic camera attached. Drawings were scanned and digitally edited, photographs were assembled using the freeware program CombineZP (HADLey 2010). The material studied is held in the larval collection of the author. Identification of adults was done using the revision of Sphaeridiinae by Smetana (1978).

Morphometry. Measurements of the head capsule and head appendages were taken with a micrometer adapted to the ocular of the microscope. Different measurements were used to calculate ratios, which are practical to characterize shapes. Measured structures were adjusted as parallel as possible to the plane of the objective. Legs and leg segments were not measured due to the extreme leg reduction.

The following measurements were taken:

AL length of antenna, derived by adding the lengths of the first (A1), second (A2) and third (A3) antennomeres;

HL head length, measured medially along epicranial stem from anterior margin of frontoclypeus to occipital foramen;

HW maximum head width;

LPL length of labial palpus, obtained by adding the lengths of the first (LP1) and second (LP2) palpomeres;

ML length of maxilla, derived by adding SL and MPL; cardo omitted;
MPL length of maxillary palpus, obtained by adding the lengths of the first (MP1), second (MP2), third (MP3) and fourth (MP4) palpomeres;

MtW maximum width of mentum;

MW maximum body width, measured at level of prothorax;

PrmtL length of prementum, measured from its base to the base of LP1;

PrmtW maximum width of prementum.

SeL length of antennal sensorium;

SL length of stipes;

TL total body length.

Chaetotaxy. Primary (present in first-instar larva) and secondary (appearing in later instars) setae and pores were identified in the cephalic capsule and head appendages. Sensilla present in first-instar larvae were labeled by comparison with the ground plan of chaetotaxy of Hydrophilidae (FIKÁČEK et al. 2008, BytTEBIER \& TORRES 2009). Homologies were established using the criterion of similarity of position (WILEY 1981). Sensilla are coded with a number and two capital letters, usually corresponding to the first two letters of the name of the structure on which they are located. Additional sensilla are coded with a black square ( $\mathbf{\square})$.

The following abbreviations were used:

$\begin{array}{ll}\text { AN } & \text { antenna; } \\ \text { FR } & \text { frontale; } \\ \text { LA } & \text { labium; } \\ \text { MN } & \text { mandible; } \\ \text { MX } & \text { maxilla; } \\ \text { PA } & \text { parietale; } \\ \text { gAN } & \text { group of antennal sensilla; } \\ \text { gAPP } & \text { group of sensilla on the inner appendage of the maxilla; } \\ \text { gFR1-2 } & \text { groups of sensilla on the frontale; } \\ \text { gLA } & \text { group of sensilla on the labial palp; } \\ \text { gMX } & \text { group of sensilla on the maxillary palp; } \\ \text { gMX2 } & \text { group of sensilla on inner margin of maxillary stipes. }\end{array}$

\section{Results \\ Oosternum costatum (LeConte, 1855) (Figs 1-22)}

Material examined. Adults of Oosternum costatum were collected in USA: Онго: Lawrence Co., v-vi.1995, Wayne National Forest, Sharps creek, Bluegrass trail, ex pig manure (P. W. Kovarik, M. Archangelsky leg.); larvae were obtained by rearing under laboratory conditions. For the descriptions two first instar (L1) and two third instar (L3) larvae were examined; one L3 larva was saved for the habitus pictures; second instar larvae were not available.

First instar larva. Morphology. Measurements and ratios in Table 1. Color. Head capsule, head appendages, thoracic and abdominal sclerotized structures light brown; membranous areas whitish. Non-sclerotized integument covered by fine and short microtrichiae. Body. Subcylindrical, wider at about midlength, slightly narrowing towards anterior end (as in Figs 1, 2 of third instar larva); legs reduced.

Head capsule (Figs 3-5). Subquadrate, broader than long; occipital foramen wide. Coronal line absent, area enclosed by frontal lines inversely bell-shaped. Stemmata closely aggregated. Clypeolabrum asymmetrical, right side slightly concave, left side with small notch bearing a patch of dense pubescence formed by fine microtrichae; lateral lobes of epistome short, rounded, not projecting farther than nasale; clypeolabrum bearing two sharp cuticular projections interpreted as egg-bursters (Fig. 5, EB). Antenna (Fig. 6). Three-segmented, A1 the longest and widest segment; 


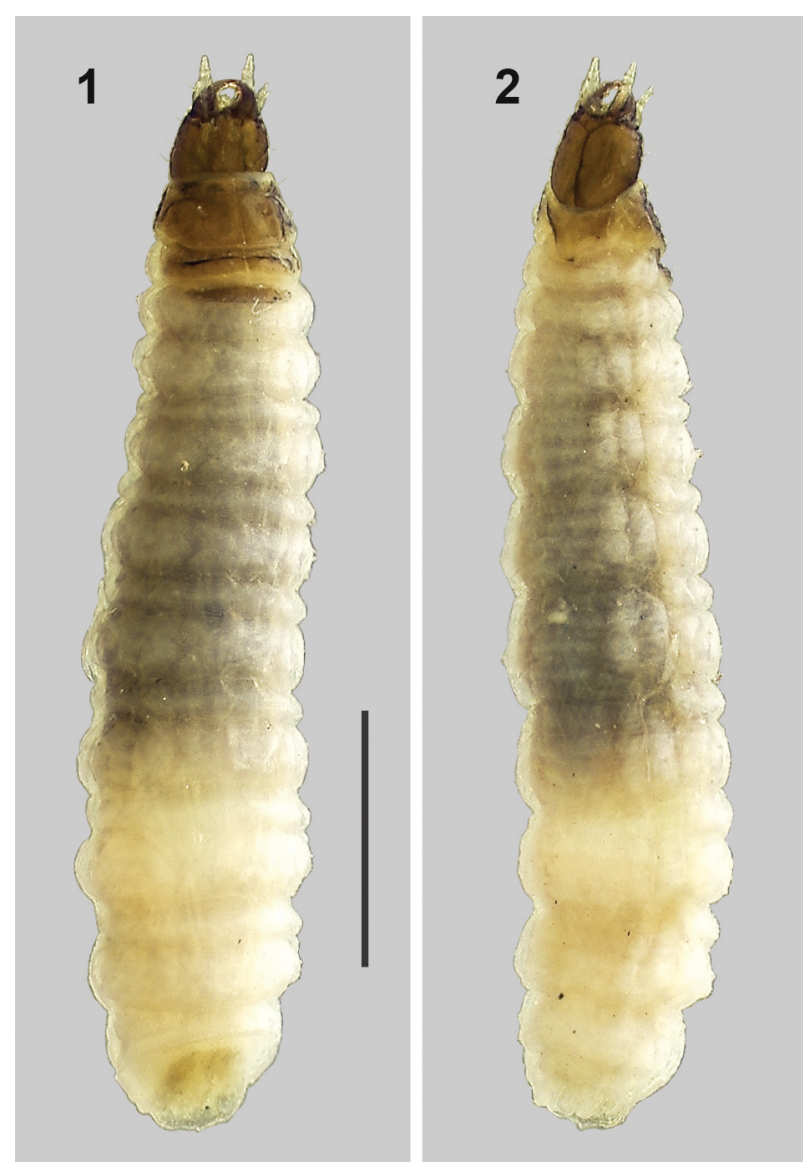

Figs 1-2. Habitus of third instar larva of O. costatum (LeConte, 1855) 1 - dorsal view; 2 - lateroventral view. Scale bar $=1 \mathrm{~mm}$.

A2 short, narrower than A1, wider than long; A3 slightly longer than A2, very narrow; SE1 subequal to A3 in length and width. Mandibles (Figs 7-8). Strongly asymmetrical, right one slightly smaller than left one, bearing one strongly serrated inner tooth, distal inner margin finely serrated; left mandible lacking inner tooth, finely serrated distally on inner margin, serration becoming stronger on central and subbasal area of inner margin. Maxilla (Figs 9-11). Six-segmented, longer than antenna, cardo subtriangular, partially covered by submentum and parietale. Stipites large, longer than palpus, strongly asymmetrical, left stipes broader than right one, dorsally bearing a band of sharp cuticular spines along distal margin. Palpus four-segmented, first palpomere the largest, subrectangular, with inner appendage reduced; second and third palpomeres shorter, wider than long; fourth palpomere the narrowest, slightly longer than wide. Labium (Figs 4, 12). Submentum large, subtriangular, fused to head capsule, with a pair of deep lateral, subapical notches. Mentum short, narrower than submentum, transversely subrectangular. Prementum reduced, as a wide and narrow subtriangular plate on ventral face. Palpi two-segmented, basal palpomere short, distal palpomere slightly longer. Ligula reduced, not sclerotized. Asymmetrical hypopharyngeal lobe as a membranous pubescent lobe developed on left side. Cervical sclerites (Fig. 3) dorsal, narrow and transverse.

Thorax. Slightly wider than head capsule, pronotal plate semicircular, wider than long, covering most of prothorax,
Table 1. Measurements (in $\mathrm{mm}$ ) and ratios for two larval instars of O. costatum (LeConte, 1855).

\begin{tabular}{|c|c|c|}
\hline Measure & Instar I & Instar III \\
\hline TL & $0.9-1.2$ & $3.5-3.9$ \\
\hline MW & $0.25-0.28$ & $0.7-0.8$ \\
\hline $\mathrm{HL}$ & 0.12 & $0.23-0.25$ \\
\hline HW & $0.17-0.18$ & $0.32-0.34$ \\
\hline HL/HW & $0.69-0.73$ & $0.72-0.73$ \\
\hline $\mathrm{AL}$ & 0.06 & $0.11-0.12$ \\
\hline A1L & 0.03 & $0.06-0.07$ \\
\hline A2L & 0.01 & $0.02-0.03$ \\
\hline A3L & $0.01-0.02$ & $0.02-0.03$ \\
\hline SEL & $0.01-0.02$ & 0.02 \\
\hline SEL/A3L & $1.07-1.25$ & $0.8-0.89$ \\
\hline A1L/A2L & $2.67-2.91$ & $2.4-2.6$ \\
\hline $\mathrm{A} 1 \mathrm{~L} /(\mathrm{A} 2 \mathrm{~L}+\mathrm{A} 3 \mathrm{~L})$ & $1.23-1.38$ & $1.24-1.37$ \\
\hline HL/AL & $2.07-2.14$ & $2.11-2.21$ \\
\hline $\mathrm{HW} / \mathrm{AL}$ & $2.85-3.07$ & $2.91-3.05$ \\
\hline SL & $0.05-0.06$ & 0.12 \\
\hline MPL & 0.04 & 0.06 \\
\hline $\mathrm{SL} / \mathrm{MPL}$ & $1.45-1.51$ & $1.92-2.0$ \\
\hline MP1L & 0.01 & $0.02-0.03$ \\
\hline MP2L & 0.01 & 0.01 \\
\hline MP3L & 0.01 & 0.01 \\
\hline MP4L & 0.01 & 0.02 \\
\hline ML & 0.09 & $0.18-0.19$ \\
\hline LPL & 0.02 & 0.04 \\
\hline LP1L & 0.01 & 0.02 \\
\hline LP2L & 0.01 & 0.02 \\
\hline LP2L/LP1L & $1.09-1.33$ & $1.13-1.19$ \\
\hline $\mathrm{MtW}$ & 0.02 & 0.05 \\
\hline PrmtW & $0.01-0.02$ & 0.04 \\
\hline PrmtL & 0.005 & 0.01 \\
\hline PrmtW/PrmtL & $3.0-3.2$ & $3.2-3.75$ \\
\hline PrmtW/MtW & $0.71-0.76$ & $0.80-0.83$ \\
\hline
\end{tabular}

divided by fine sagittal line; mesonotum and metanotum lacking sclerotized plates. Prosternal plate subtriangular, transverse, lacking sagittal line, shorter than pronotal plate; meso- and metasternum membranous. Legs unsclerotized, reduced to a small membranous lobe bearing patch of short setae. Mesothoracic spiracles non-functional.

Abdomen. Ten-segmented, segments IX and X modified (as in Fig. 1 of third-instar larva). Segments I to VII subequal in size and shape, lacking sclerites, subdivided by transverse folds. Segment VIII with large dorsal plate, posteriorly lobed; with a short pair of procerci laterad to dorsal plate. Segment IX trilobed, with a pair of one-segmented urogomphi. Spiracles on segments I-VII biforous, non-functional; those on segment VIII large, annular.

Primary chaetotaxy. Head capsule (Figs 2-12). Frontale with 28 sensilla: one pair of short setae on basal quarter close to frontal lines (FR1); two pores (FR2) and two very short setae (FR3) close to midline at about midlength; two pairs of setae laterad to FR3 closely aggregated (FR5 long, FR6 short); one pair of pores posterior to inner margin of antennal sockets (FR4); one pair of pores (FR15) posterior to egg-bursters (EB); six pairs of sensilla distal to inner margin of antennal socket, four setae (FR8 short, FR9 broken, probably long as in third instar larva and FR10 



Figs 3-4. Chaetotaxy of first instar larva of O. costatum (LeConte, 1855). 3 - head capsule, dorsal view; 4 - head capsule, ventral view. Scale bar $=0.05 \mathrm{~mm}$. 

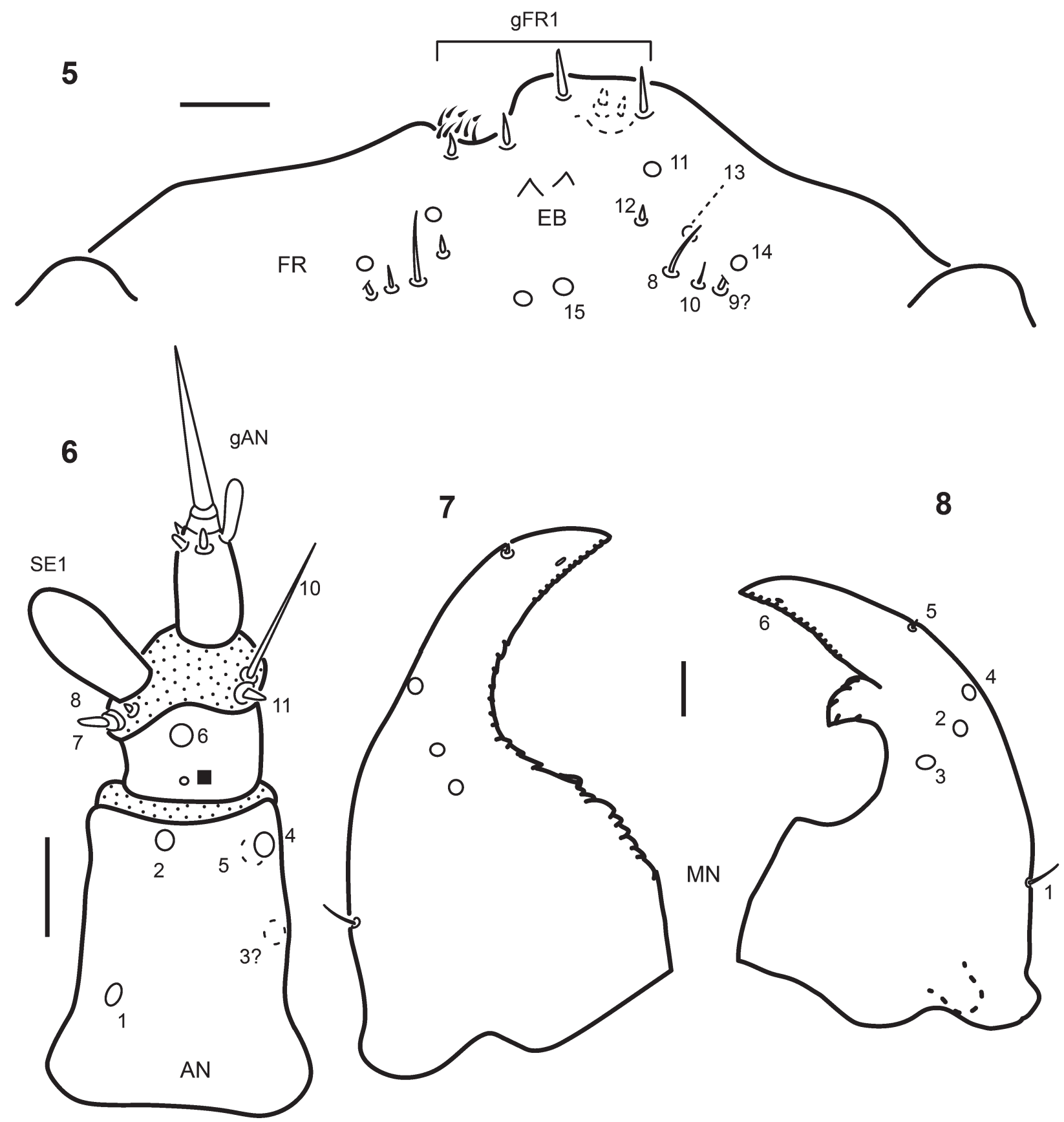

Figs 5-8. Chaetotaxy of first instar larva of $O$. costatum (LeConte, 1855). 5 - detail of clypeolabrum; 6 - left antenna, dorsal view; 7 - left mandible, dorsal view; 8 - right mandible, dorsal view. Scale bars $=0.01 \mathrm{~mm}$.

and FR12 very short) and two pores (FR11, FR13); nasale with gFR1 bearing four dorsal short and rather stout setae, and a pair of small setae inserted ventrally; left two setae of gFR1 slightly shorter. Epistomal lobes lacking sensilla, therefore gFR2 absent. Seta FR7 apparently absent, pore FR14 present. Each parietale with 30 sensilla: dorsal surface with a basal group of four minute setae (PA1, PA2, PA4, PA5) and one pore (PA3) arranged in an almost L- or semicircular shape; one basal pore (PA6) almost touching frontal line; seta PA7 short, close to PA5; setae PA12, PA13, PA14 closely aggregated on lateral margin at about midlength, one very long and two shorter; setae PA8 (long), PA11 (short) and pore (PA10) in a transverse row past midlength; two setae (PA9 long, PA20 short) and pore (PA19) in a transverse row on anterolateral corner of head capsule. Ventral surface with three pores (PA23, PA24, PA25) and two setae (PA21 long, PA22 short) on anterolateral corner, close to mandibular acetabulum; one pore (PA15) on lateral surface at about midlength; setae PA16 (long) and PA26 (shorter), and pore PA17 closely grouped; pore PA27 and seta PA28 (broken, probably long) close to midline; pores PA29 and PA30, and long seta PA18 forming a transverse line at about basal third.

Antenna (Fig. 6). A1 bare, with five pores, three dorsal ones on dorsal surface (AN1 basal, AN2 distal on midline, AN4 distal on inner margin) and two ventral ones close to inner surface (AN3 at midlength, AN5 distal). A2 with two pores, one distal (AN6) and one subbasal ( $\mathbf{a})$, and four 


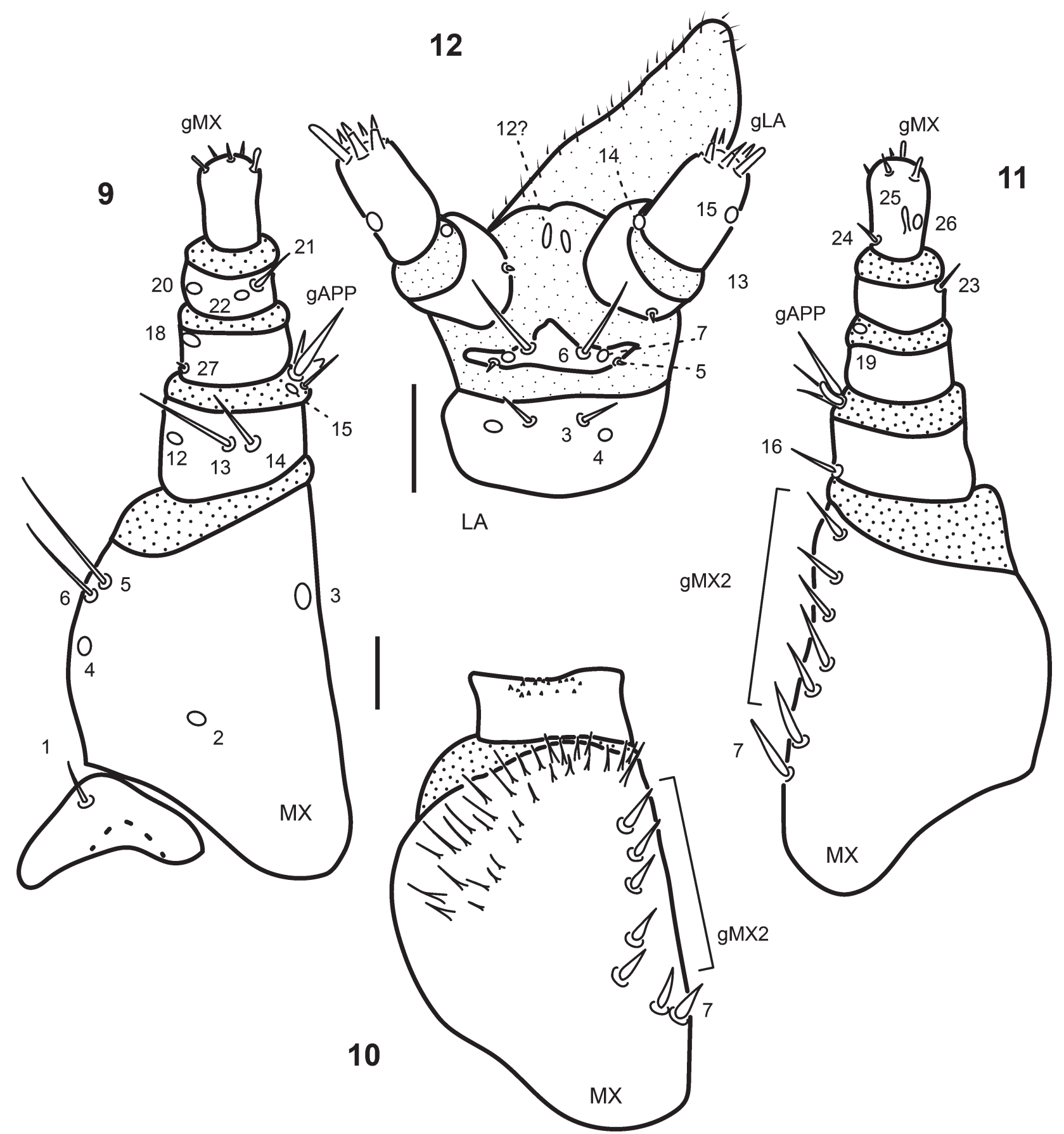

Figs 9-12. Chaetotaxy of first instar larva of $O$. costatum (LeConte, 1855). 9 - left maxilla, ventral view; 10 - left stipes, dorsal view; 11 - right maxilla, dorsal view; $12-$ labium, ventral view. Scale bars $=0.01 \mathrm{~mm}$.

setae, two very short subapical on outer face (AN7, AN8) close to base of SE1, and two subapical on inner margin (AN10 long, AN11 very short). A3 with a distal group of at least three very short setae, one short sensorium and one long seta (gAN).

Mandibles (Figs 7-8). Both mandibles with six sensilla; one short seta on outer margin at basal quarter (MN1), one minute seta on outer margin at distal quarter (MN5) in right mandible (closer to apex in left mandible), three dorsal pores (MN2, MN3, MN4) forming an oblique row at level of inner retinaculum of right mandible; pore MN6 small, subapical on inner margin, difficult to see.

Maxilla (Figs 9-11). Cardo with one short seta (MX1).
Stipes with a row of seven stout and short setae along inner margin, basal seta of that row likely homologous to MX7, remaining setae forming gMX2; left stipes with MX7 and basal two setae of gMX2 arranged in an oblique row, distal four in a longitudinal row; ventral face with three pores, one on basal third (MX2), one on distal third close to inner margin (MX3) and one at midlength on outer margin (MX4), and two setae distal to pore MX4 (MX5 long, MX6 slightly shorter). MP1 dorsally with one basal seta on inner face (MX16), pore MX17 apparently absent; ventrally with two setae (MX13 long, MX14 shorter) and two pores (MX12 on outer margin, MX15 on inner margin at base of gAPP); inner appendage reduced, with several 


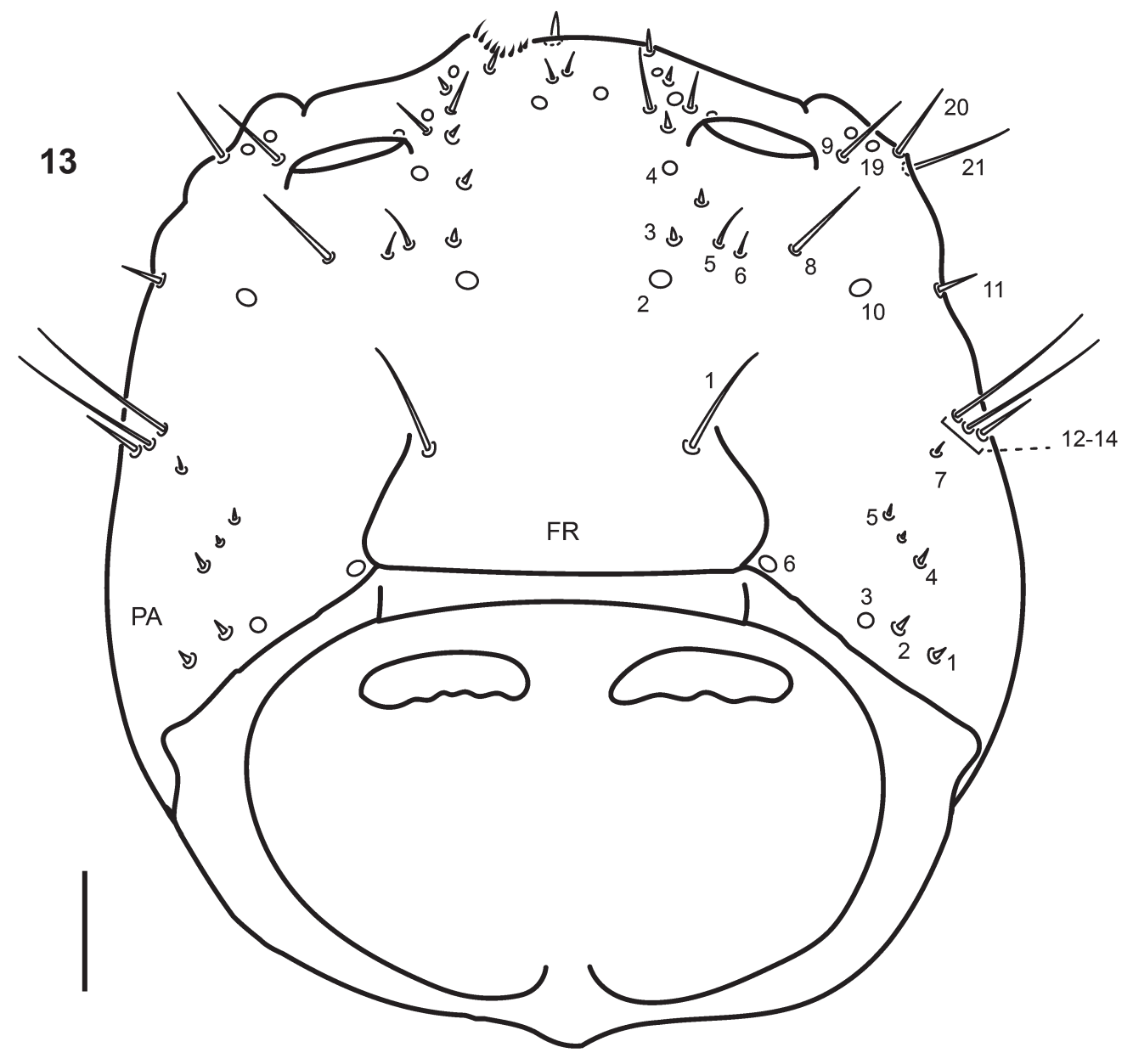

14

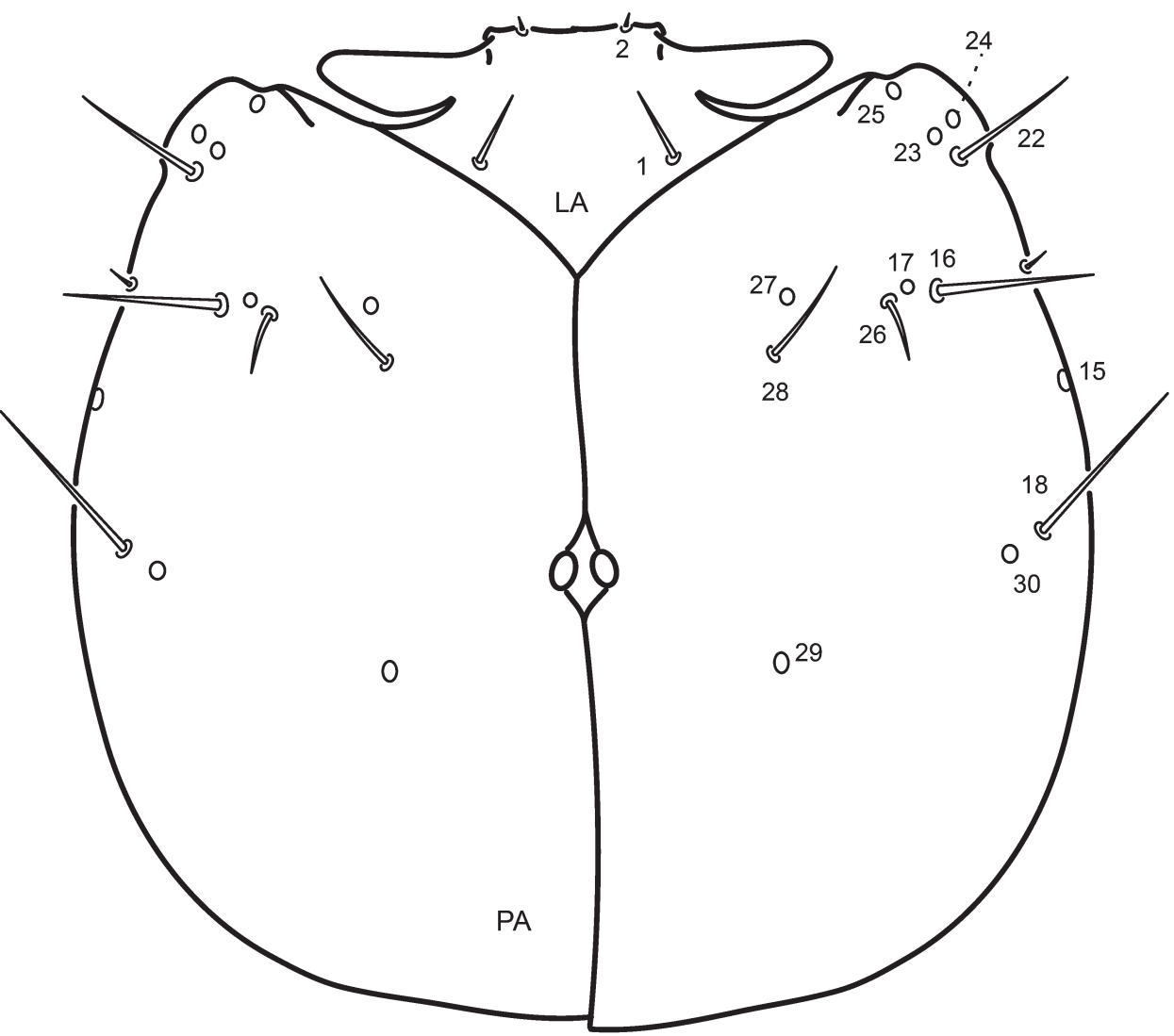

Figs 13-14. Chaetotaxy of third instar larva of $O$. costatum (LeConte, 1855). 13 - head capsule, dorsal view; 14 - head capsule, ventral view. Scale bar $=0.05 \mathrm{~mm}$. 

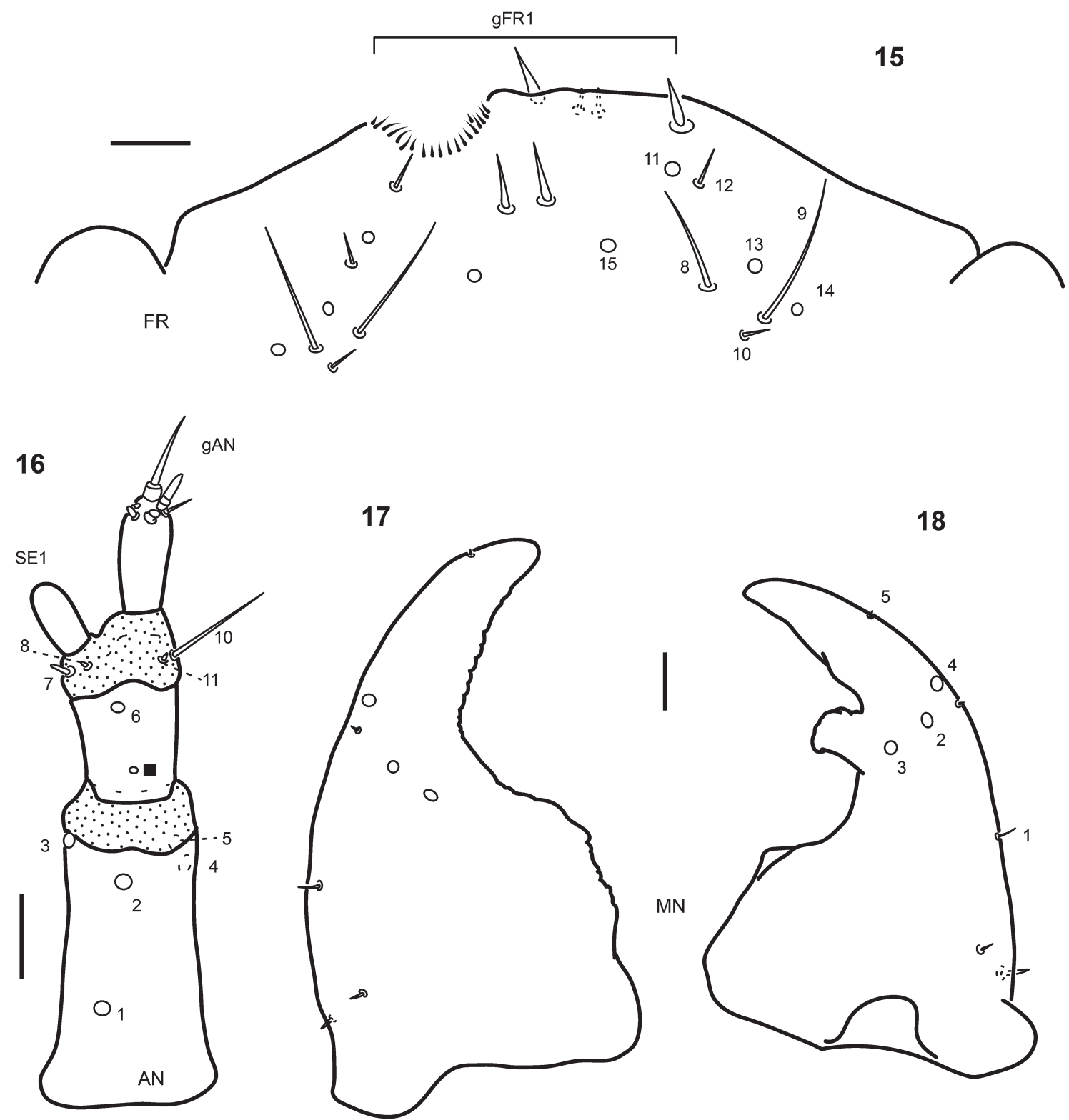

Figs 15-18. Chaetotaxy of third instar larva of $O$. costatum (LeConte, 1855). 15 - detail of clypeolabrum; 16 - left antenna, dorsal view; 17 - left mandible, dorsal view; 18 - right mandible, dorsal view. Scale bars $=0.02 \mathrm{~mm}$.

setae of different lengths (gAPP). MP2 with two pores, one ventral and apical on outer margin (MX18) and one dorsal at inner margin on membrane connecting with MP3 (MX19); one basal minute seta (MX27) on outer margin. MP3 with two short setae and two pores, one seta dorsal, on outer margin (MX23), the other ventral on inner margin (MX21); both pores on ventral surface, one close to seta MX21 (MX22), the other apical, close to outer margin (MX20). MP4 with one short basal seta dorsally (MX24) and two dorsal subapical pores (MX25 central, digitiform, MX26 closer to outer margin); a group of five or six very short sensilla constitute gMX1.

Labium (Figs 4, 12). Submentum with two pairs of setae (Fig. 4), one long (LA1), the other minute, on anterior margin (LA2). Mentum ventrally with one pair of short setae (LA3) and one pair of lateral pores (LA4). Prementum with two pairs of setae (LA6 rather long, close to midline, LA5 minute, lateral) and one pair of pores (LA7) between LA5 and LA6. Sensilla associated with ligula absent (LA9-12) except for one pair of pores (LA12?), resembling LA12 placed on membranous lobe between labial palpi (behind palpi in ventral view). LP1 with one minute seta (LA13, ventral) and one distal pore (LA14, on inner margin); LP2 with one subapical pore on outer face (LA15) and a group of at least five short sensilla constituting gLA.

Third-instar larva. Morphology (Figs 1-2, 13-22). Measurements and ratios in Table 1 . Head capsule, head appendages, thoracic and abdominal sclerotized structures darker. Frontal lines visible basally. Antennae more slender and longer, A2 longer than wide. Pronotal plate larger, subrectangular, with sagittal line; mesonotal and metanotal plates present, smaller; mesonotal plate ca. 1/2 the length of pronotal plate, metanotal plate ca. $1 / 2$ the length of mesonotal plate. Pleural plates present on pronotum; prosternal plate larger, slightly shorter than pronotal plate. Legs with a membranous coxal area and a minute sclerotized segment. 


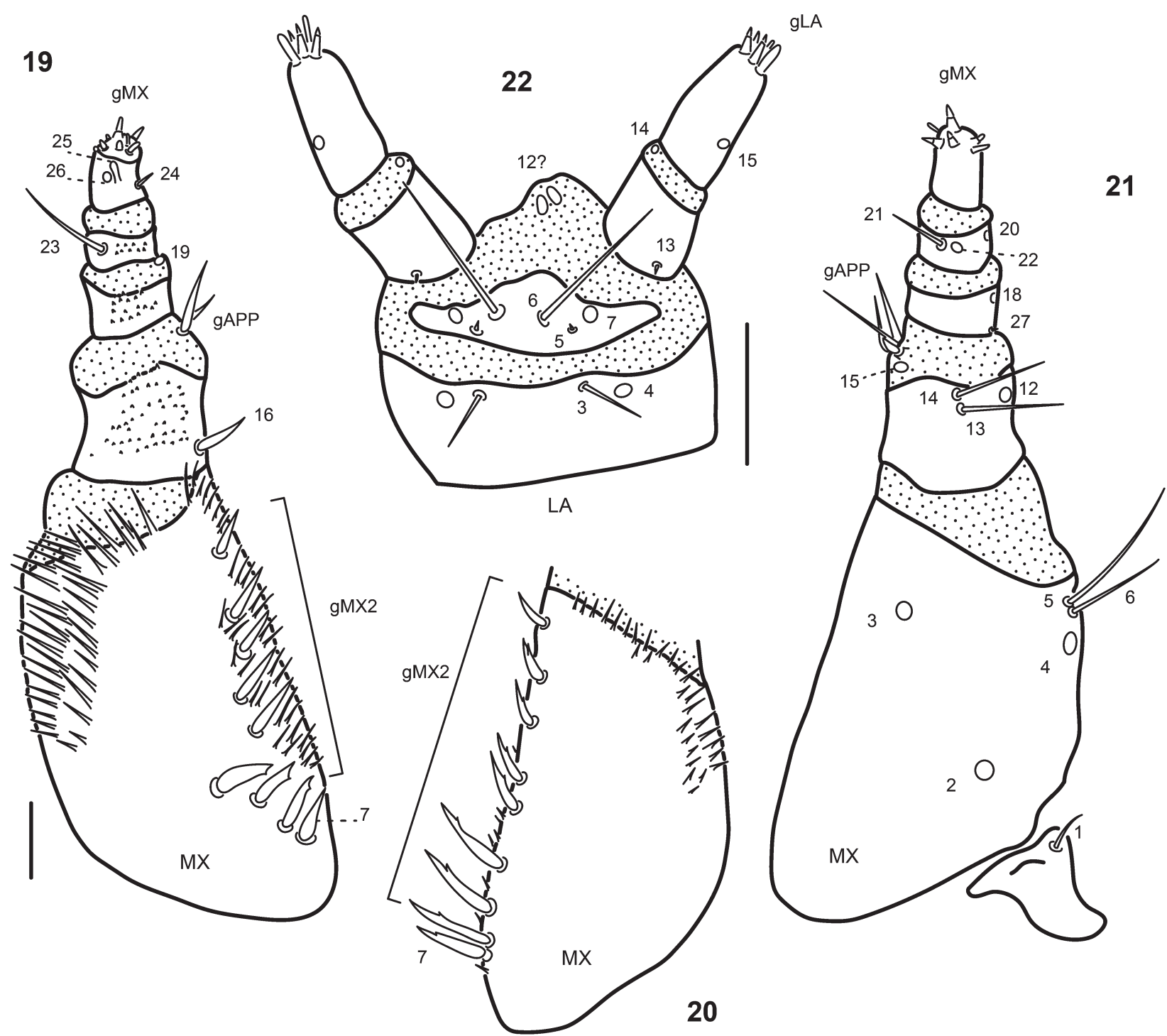

Figs 19-22. Chaetotaxy of third instar larva of $O$. costatum (LeConte, 1855). 19 - left maxilla, dorsal view; 20 - right stipes, dorsal view; 21 - left maxilla, ventral view; 22 - labium, ventral view (hypopharyngeal lobe not included). Scale bars $=0.02 \mathrm{~mm}$.

Right stipes with cuticular projections along inner and distal margins; left stipes with long cuticular projections along inner, distal and outer margins. MP1-3 with short and sharp cuticular projections on dorsal face.

Chaetotaxy. Head capsule (Figs 13-22). Frontale with one secondary short seta between FR3 and FR4; pore FR14 distinguishable, close to FR9; seta FR1 proportionally longer, FR5 proportionally shorter; gFR1 with seven setae, five dorsal and two ventral. Each parietale with three secondary sensilla; one minute seta between PA4 and PA5, one short seta on outer margin near PA11 and one pore between seta PA9 and pore PA19; seta PA7 very short; seta PA8 proportionally shorter, group of setae PA12-14 with two long and one short seta; seta PA22 proportionally longer. Antenna (Fig. 16). Without secondary sensilla, sensory appendage distinctly shorter and slightly narrower than third antennomere. Mandibles (Figs 17-18). Each mandible with three secondary setae, two short setae on basal outer face, behind MN1, third one minute, close to pore MN4. Maxilla (Figs 19-21). Stipes without secondary setae on ventral face; dorsal face with two secondary setae on gMX2, basal seven setae of right gMX2 bifid apically, basal three setae of left gMX2 bifid; MX7 on right stipes bifid; maxillary palpomeres lacking secondary sensilla. Labium (Figs 14, 22). Without secondary sensilla, LA6 proportionally longer; pore LA7 located laterad of LA5.

\section{Discussion}

Larvae of Oosternum costatum share many characters in common with known larvae of Cercyon, Armostus and Motonerus (ARChAngelsky 2016; Minoshima in press; Fikáček, unpubl. data), and also with other Megasternini larvae for which the general morphology is known but the chaetotaxy has not been described in detail yet (Cryptopleurum and Pelosoma; Archangelsky 1997). All these characters are listed in Table 2, together with some characters that differ between Megasternini and Sphaeridiini larvae. Differences among known Megasternini larvae have been listed in Table 3; the only genus not included in this table 
is Megasternum, since I have not seen any material and all the information on this genus comes from older papers that do not include a detailed chaetotaxic description (PHILLIPS 1923; Böving \& HeNRIKSEN 1938; QueNNEdey 1965). Below is a discussion on those characters that have phylogenetic importance for known larvae of Megasternini and also that support the monophyly of Megasternini + Sphaeridiini.

Larval synapomorphies of Megasternini. Several larval characters support the monophyly of Megasternini (Table 2). Egg-bursters (char. 1) are present in all known Megasternini larvae, and also in those of Sphaeridium Fabricius, 1775 and at least some Dactylosternum Wollaston, 1854 (Coelostomatini), but the morphology of these egg-bursters is rather different (FIKÁČEK 2006; ARCHANGELSKY 2016; ARCHANGELSKY et al. 2016; Minoshima in press; Fikáček, unpubl. data). In Megasternini they are represented by two small toothlets behind the centralmost dorsal setae of gFR1; in Sphaeridium they form a longitudinal row of four small toothlets, while in Dactylosternum cacti (LeConte, $1855)$ they appear as two strong setae (centralmost setae of gFR1) placed on a small lobe. A small basal additional pore on A2 (char. 9) seems to be exclusive of Megasternini larvae although they may appear as a small cuticular tooth in some Cercyon and Motonerus larvae (FIKÁčEK 2006; Fikáček, unpubl. data). Similar pore-like sensoria have been observed in larvae of some Hydrobiusini and other genera (e.g. Rygmodus White, 1846, Laccobius Erichson, 1837, Enochrus Thomson, 1859) in a similar position in second and third instar larvae, probably a convergence (Minoshima et al. 2011, 2017, 2018; Archangelsky, unpubl. data). Mandibular asymmetry (char. 10) in which the left mandible lacks a retinaculum while the right one has one retinaculum also seems to be exclusive of Megasternini larvae, at least within Sphaeridiinae; Sphaeridium has asymmetrical mandibles, but both lack retinacula. The strongly reduced ligula (char. 17) is convergent with some hydrophilid larvae included in the clades Coelostomatini, Berosini, Laccobiini and Cylominae; these are most likely convergences related to feeding modes. Pore LA11 (char. 18) can also be considered a synapomorphy of Megasternini, since it is present in most known Sphaeridiinae except for some Dactylosternum (e.g. Dactylosternum cacti) that have mouthpart modifications convergent with those of Megasternini (e.g. reduced ligula and left hypo-

Table 2. Comparative table of morphological and chaetotaxic characters among larvae of Megasternini and Sphaeridiini.

\begin{tabular}{|c|c|c|c|c|c|c|c|}
\hline \multirow[t]{2}{*}{ Character } & \multicolumn{6}{|c|}{ Megasternini } & \multirow{2}{*}{$\begin{array}{l}\text { Sphaeridiini } \\
\text { Sphaeridium }\end{array}$} \\
\hline & Armostus & Cercyon & Cryptopleurum & Motonerus* & Oosternum & Pelosoma & \\
\hline Egg-bursters & $\begin{array}{l}\text { present, } 2 \\
\text { toothlets }\end{array}$ & $\begin{array}{l}\text { present, } 2 \\
\text { toothlets }\end{array}$ & $\begin{array}{l}\text { present present, } \\
2 \text { toothlets }\end{array}$ & $?$ & $\begin{array}{l}\text { present, } 2 \\
\text { toothlets }\end{array}$ & $\begin{array}{l}\text { present, } 2 \\
\text { toothlets }\end{array}$ & $\begin{array}{l}\text { present, } 4 \\
\text { toothlets }\end{array}$ \\
\hline gFR2 & absent & absent & absent & absent & absent & absent & absent \\
\hline Frontal lines & $\begin{array}{l}\text { widely separa- } \\
\text { ted basally }\end{array}$ & $\begin{array}{l}\text { widely separa- } \\
\text { ted basally }\end{array}$ & $\begin{array}{l}\text { widely separa- } \\
\text { ted basally }\end{array}$ & $\begin{array}{l}\text { widely separa- } \\
\text { ted basally }\end{array}$ & $\begin{array}{l}\text { widely separa- } \\
\text { ted basally }\end{array}$ & $\begin{array}{l}\text { widely separa- } \\
\text { ted basally }\end{array}$ & $\begin{array}{l}\text { widely sepa- } \\
\text { rated basally }\end{array}$ \\
\hline $\begin{array}{l}\text { Notch on left side of } \\
\text { nasale }\end{array}$ & present & present & present & present & present & present & present \\
\hline PA1-3 & $\begin{array}{l}\text { in a transverse } \\
\text { row }\end{array}$ & $\begin{array}{l}\text { in a transverse } \\
\text { row }\end{array}$ & $\begin{array}{l}\text { in a transverse } \\
\text { row }\end{array}$ & $\begin{array}{l}\text { in a transverse } \\
\text { row }\end{array}$ & $\begin{array}{l}\text { in a transverse } \\
\text { row }\end{array}$ & $\begin{array}{l}\text { in a transverse } \\
\text { row }\end{array}$ & $\begin{array}{l}\text { in a transver- } \\
\text { se row }\end{array}$ \\
\hline PA6 & $\begin{array}{l}\text { basal near } \\
\text { frontal line }\end{array}$ & $\begin{array}{l}\text { basal near } \\
\text { frontal line }\end{array}$ & $\begin{array}{l}\text { basal near } \\
\text { frontal line }\end{array}$ & $\begin{array}{l}\text { basal near } \\
\text { frontal line }\end{array}$ & $\begin{array}{l}\text { basal near } \\
\text { frontal line }\end{array}$ & $\begin{array}{l}\text { basal near } \\
\text { frontal line }\end{array}$ & $\begin{array}{l}\text { basal near } \\
\text { frontal line }\end{array}$ \\
\hline $\mathrm{MN} 2-4$ & $\begin{array}{l}\text { in an oblique } \\
\text { row }\end{array}$ & $\begin{array}{l}\text { in an oblique } \\
\text { row }\end{array}$ & $\begin{array}{l}\text { in an oblique } \\
\text { row }\end{array}$ & $\begin{array}{l}\text { in an oblique } \\
\text { row }\end{array}$ & $\begin{array}{l}\text { in an oblique } \\
\text { row }\end{array}$ & $\begin{array}{l}\text { in an oblique } \\
\text { row }\end{array}$ & $\begin{array}{l}\text { in an oblique } \\
\text { row }\end{array}$ \\
\hline MN5 & $\begin{array}{l}\text { more apical in } \\
\text { left mandible }\end{array}$ & $\begin{array}{l}\text { more apical in } \\
\text { left mandible }\end{array}$ & $\begin{array}{l}\text { more apical in } \\
\text { left mandible }\end{array}$ & $\begin{array}{l}\text { more apical in } \\
\text { left mandible }\end{array}$ & $\begin{array}{l}\text { more apical in } \\
\text { left mandible }\end{array}$ & $\begin{array}{l}\text { more apical in } \\
\text { left mandible }\end{array}$ & $\begin{array}{l}\text { more apical in } \\
\text { left mandible }\end{array}$ \\
\hline $\begin{array}{l}\text { Additional basal pore } \\
\text { on A2 }\end{array}$ & present & present & present & $\begin{array}{l}\text { present (as a } \\
\text { spine) }\end{array}$ & present & present & absent \\
\hline $\begin{array}{l}\text { Mandibular retinac- } \\
\text { ulum }\end{array}$ & $\begin{array}{l}\text { present on } \\
\text { right mandible }\end{array}$ & $\begin{array}{l}\text { present on } \\
\text { right mandible }\end{array}$ & $\begin{array}{l}\text { present on right } \\
\text { mandible }\end{array}$ & $\begin{array}{l}\text { present on } \\
\text { right mandible }\end{array}$ & $\begin{array}{l}\text { present on } \\
\text { right mandible }\end{array}$ & $\begin{array}{l}\text { present on } \\
\text { right mandible }\end{array}$ & $\begin{array}{l}\text { absent on ri- } \\
\text { ght mandible }\end{array}$ \\
\hline Stipital asymmetry & present & present & present & present & present & present & present \\
\hline $\begin{array}{l}\text { Appendage of first } \\
\text { maxillary palpomere }\end{array}$ & reduced & reduced & reduced & reduced & reduced & reduced & reduced \\
\hline Pore MX17 & absent & absent & absent & absent & absent & absent & absent \\
\hline MX25-26 & dorsal & dorsal & dorsal & $\begin{array}{l}\text { ? MX26 not } \\
\text { found }\end{array}$ & dorsal & dorsal & dorsal \\
\hline Hypopharyngeal lobe & present & present & present & present & present & present & present \\
\hline Ligula & $\begin{array}{l}\text { strongly } \\
\text { reduced }\end{array}$ & $\begin{array}{l}\text { strongly } \\
\text { reduced }\end{array}$ & $\begin{array}{l}\text { strongly redu- } \\
\text { ced }\end{array}$ & $\begin{array}{l}\text { strongly } \\
\text { reduced }\end{array}$ & $\begin{array}{l}\text { strongly } \\
\text { reduced }\end{array}$ & $\begin{array}{l}\text { strongly } \\
\text { reduced }\end{array}$ & $\begin{array}{l}\text { well develo- } \\
\text { ped }\end{array}$ \\
\hline Pore LA11 & absent & absent & absent & absent & absent & absent & present \\
\hline Legs & $\begin{array}{l}\text { strongly } \\
\text { reduced }\end{array}$ & $\begin{array}{l}\text { strongly } \\
\text { reduced }\end{array}$ & $\begin{array}{l}\text { strongly re- } \\
\text { duced }\end{array}$ & $\begin{array}{l}\text { strongly } \\
\text { reduced }\end{array}$ & $\begin{array}{l}\text { strongly } \\
\text { reduced }\end{array}$ & $\begin{array}{l}\text { strongly } \\
\text { reduced }\end{array}$ & $\begin{array}{l}\text { reduced but } \\
5 \text {-segmetned }\end{array}$ \\
\hline
\end{tabular}

*Larval morphology of Motonerus was described based on third instar larvae, characters related to first instars are unknown (e.g. egg-bursters). 
pharyngeal lobe well developed); LA11 is also missing in some other hydrophilid larvae that show ligular reduction such as Laccobius, this probably represents a convergence. Leg reduction is another character that defines Megasternini larvae, all known larvae exhibit strongly reduced legs which range from 2-segmented to completely reduced legs represented only by small setose lobes. Within Sphaeridiinae leg reduction is seen in Sphaeridium, but in this genus the legs are still 5-segmented.

Larval synapomorphies of Megasternini + Sphaeridiini. There is an important number of synapomorphies supporting the clade Megasternini + Sphaeridiini $(M+S)$, suggesting a close relationship between these two tribes (Table 2). The absence of gFR2 (char. 2) is exclusive of this clade, being Spercheus Kugelann, 1798 (Spercheidae) the only other known hydrophiloid genus that shows this trait (a convergence). Frontal lines widely separated at base of head capsule (char. 3) is another synapomorphy for $\mathrm{M}+\mathrm{S}$, but this trait is convergent with larvae included in other clades such as Berosini, some Chaetarthriinae and Cylominae. An exclusive character of $\mathrm{M}+\mathrm{S}$ is the presence of a small notch on the left side of the nasale bearing a patch of short and dense pubescence (char. 4), so far no other known hydrophiloid larvae share this character. The position of sensilla PA1-3 arranged in a transverse row at base of parietale (char. 5), and not in line with PA4-5 is also characteristic of this clade; in other known hydrophilid larvae PA1-5 appear in a more or less longitudinal or oblique line. Pore PA6 basal, almost touching the frontal line (char. 6), is unique of $\mathrm{M}+\mathrm{S}$ within Sphaeridiinae; nonetheless a similar position of PA6 is observed in Derallus Sharp, 1882 (Berosini) while in other Berosini this pore is close but never so close as to touch the lines; in Laccobius larvae pore PA6 is located in a membranous area behind the frontal line (FIKÁČEK 2006; Minoshima et al. 2017). Mandibles with pores MN2-4 arranged in an oblique row (char. 7) appears as another synapomorphy of this clade (within Sphaeridiinae, in most hydrophilid larvae these pores form a triangle); nevertheless some Hydrophilini larvae share this trait, but this should be considered a convergence (FIKÁČEK 2006, MinOSHIMA \& HAYASHI, 2011, Torres et al. 2014; pers. obs.). Sensillum MN5 positioned more distally in left mandible than in

Table 3. Differences among known Megasternini larvae.

\begin{tabular}{|c|c|c|c|c|c|c|}
\hline Character & Armostus & Cercyon & Cryptopleurum & Motonerus* & Oosternum & Pelosoma \\
\hline Dorsal surface of head & $\begin{array}{l}\text { with bulge-like } \\
\text { microsculpture }\end{array}$ & smooth & smooth & $\begin{array}{l}\text { with spine-like } \\
\text { micorsculpture }\end{array}$ & smooth & smooth \\
\hline Pores FR13 and FR15 & present & present & present & absent & present & present \\
\hline Pores FR15 & $\begin{array}{l}\text { separated, } \\
\text { at sides of } \\
\text { egg-bursters }\end{array}$ & $\begin{array}{l}\text { separated, } \\
\text { at sides of } \\
\text { egg-bursters }\end{array}$ & $\begin{array}{l}\text { separated, } \\
\text { at sides of } \\
\text { egg-bursters }\end{array}$ & absent & $\begin{array}{l}\text { close to each } \\
\text { other, behind } \\
\text { egg-bursters }\end{array}$ & $\begin{array}{l}\text { separated, } \\
\text { at sides of } \\
\text { egg-bursters }\end{array}$ \\
\hline $\begin{array}{l}\text { Patch of cuticular } \\
\text { projections on left } \\
\text { mandible }\end{array}$ & present & $\begin{array}{l}\text { absent or pres- } \\
\text { ent }\end{array}$ & absent & absent & absent & present, minute \\
\hline Seta PA7 & long & short or long & short & long & short & long \\
\hline Setae PA12-14 & $\begin{array}{l}\text { not closely } \\
\text { grouped }\end{array}$ & $\begin{array}{l}\text { closely } \\
\text { grouped }\end{array}$ & closely grouped & $\begin{array}{l}\text { not closely } \\
\text { grouped }\end{array}$ & $\begin{array}{l}\text { closely } \\
\text { grouped }\end{array}$ & $\begin{array}{l}\text { not closely } \\
\text { grouped }\end{array}$ \\
\hline $\begin{array}{l}\text { Antennal sensorium } \\
\left(3^{\text {rd }} \text { instars }\right)\end{array}$ & as long as $\mathrm{A} 3$ & shorter than A3 & as long as $\mathrm{A} 3$ & $\begin{array}{l}\text { much longer } \\
\text { than A3 }\end{array}$ & shorter than A3 & as long as $\mathrm{A} 3$ \\
\hline $\begin{array}{l}\text { Retinaculum of right } \\
\text { mandible }\end{array}$ & single & single & single & bifid & single & single \\
\hline $\begin{array}{l}\text { Right stipes of first } \\
\text { instars }\end{array}$ & $\begin{array}{l}\text { with cuticular } \\
\text { projections }\end{array}$ & $\begin{array}{l}\text { with cuticular } \\
\text { projections }\end{array}$ & $\begin{array}{l}\text { with cuticular } \\
\text { projections }\end{array}$ & $?$ & $\begin{array}{l}\text { lacks cuticular } \\
\text { projections }\end{array}$ & $\begin{array}{l}\text { with cuticular } \\
\text { projections }\end{array}$ \\
\hline Setae of gMX2 & $\begin{array}{l}\text { both stipites } \\
\text { with similar } \\
\text { number of } \\
\text { setae }\end{array}$ & $\begin{array}{l}\text { both stipites } \\
\text { with similar } \\
\text { number of } \\
\text { setae }\end{array}$ & $\begin{array}{l}\text { both stipites } \\
\text { with similar } \\
\text { number of setae }\end{array}$ & $\begin{array}{l}\text { left stipes with } \\
9 \text { setae, right } \\
\text { one with } 6\end{array}$ & $\begin{array}{l}\text { both stipites } \\
\text { with similar } \\
\text { number of } \\
\text { setae }\end{array}$ & $\begin{array}{l}\text { both stipites } \\
\text { with similar } \\
\text { number of } \\
\text { setae }\end{array}$ \\
\hline Seta LA6 & $\begin{array}{l}\text { as long as or } \\
\text { longer than } \\
\text { labial palpus }\end{array}$ & $\begin{array}{l}\text { as long as or } \\
\text { longer than } \\
\text { labial palpus }\end{array}$ & $\begin{array}{l}\text { as long as or } \\
\text { longer than } \\
\text { labial palpus }\end{array}$ & $\begin{array}{l}\text { as long as or } \\
\text { longer than } \\
\text { labial palpus }\end{array}$ & $\begin{array}{l}\text { shorter than } \\
\text { labial palpus }\end{array}$ & $\begin{array}{l}\text { as long as or } \\
\text { longer than } \\
\text { labial palpus }\end{array}$ \\
\hline $\begin{array}{l}\text { Second maxillary pal- } \\
\text { pomere }\end{array}$ & $\begin{array}{l}\text { incompletely } \\
\text { sclerotized } \\
\text { dorsally }\end{array}$ & $\begin{array}{l}\text { ring-like, com- } \\
\text { pletely sclero- } \\
\text { tized }\end{array}$ & $\begin{array}{l}\text { ring-like, com- } \\
\text { pletely sclero- } \\
\text { tized }\end{array}$ & $\begin{array}{l}\text { ring-like, com- } \\
\text { pletely sclero- } \\
\text { tized }\end{array}$ & $\begin{array}{l}\text { ring-like, com- } \\
\text { pletely sclero- } \\
\text { tized }\end{array}$ & $\begin{array}{l}\text { ring-like, com- } \\
\text { pletely sclero- } \\
\text { tized }\end{array}$ \\
\hline Legs ( $3^{\text {rd }}$ instar $)$ & two-segmented & $\begin{array}{l}\text { two-segmented } \\
\text { or unsclero- } \\
\text { tized, as a } \\
\text { small setose } \\
\text { lobe }\end{array}$ & $\begin{array}{l}\text { unsclerotized, } \\
\text { as a small setose } \\
\text { lobe }\end{array}$ & $\begin{array}{l}\text { unsclerotized, } \\
\text { as a small } \\
\text { setose lobe }\end{array}$ & one-segmented & one-segmented \\
\hline
\end{tabular}

*Larval morphology of Motonerus was described based on third instar larvae, characters related to first instars are unknown (e.g. egg-bursters). 
right one (char. 8) is also unique within hydrophilid larvae; a reverse situation, where MN5 is more distal in the right mandible is seen in some Hydrophilus Geoffroy larvae (FikÁČEK 2006, Minoshima \& HAYASHI, 2011; pers. obs.). A strong stipital asymmetry (char. 11) also supports the clade $\mathrm{M}+\mathrm{S}$, a detailed discussion of this character can be found in ARCHANGELSKY (2016). The reduction of the inner appendage of the first maxillary palpomere (char. 12) is characteristic of the clade $\mathrm{M}+\mathrm{S}$, this appendage is present in all known larvae of the other sphaeridiine tribes; the only genus in which this appendage is reduced to a membranous or poorly sclerotized appendage, is Paracymus Thomson, 1867 (ARCHANGELSKY 1997, 1999b). The absence of pore MX17 (char. 13) is probably related to the reduction of the inner appendage of the first maxillary palpomere, and is also unique to the clade $\mathrm{M}+\mathrm{S}$; nonetheless MinOSHIMA \& HAYASHI (2012) reported that pores MX15 and MX17 are missing in Amphiops. The position of sensilla MX25 and MX26 dorsally on the fourth palpomere (char. 14) is characteristic of the clade $\mathrm{M}+\mathrm{S}$; the other genera with a similar position of these sensoria are Tormus Sharp, 1884 and Tritonus Mulsant, 1844 (both within Laccobiini) (FIKÁČEK et al. 2013, 2017); in Coelostomatini MX25 is dorsal and MX26 is ventral, in Omicrini and Protosternini the placement of these sensilla is unknown. A well-developed hypopharyngeal lobe (char. 15 ) is present in the clade $\mathrm{M}+\mathrm{S}$; however this character is also present in some Coelostomatini such as Dactylosternum (ARCHANGELSKY 1994, 1999a, 2016) and in some members of the subfamily Cylominae such as Austrotypus Fikáček, Minoshima \& Newton, 2014, see FIKÁČEK et al. (2014), this could be considered a convergence.

Final remarks. The significant number of larval characters shared by Megasternini larvae clearly surpass the number of differences among these genera. This clearly and strongly supports the monophyly of Megasternini, and these larval characters could be tentatively used as diagnostic for the tribe. However this should be taken with care since larvae are known for only seven of the 50 genera of this diverse tribe, and chaetotaxic information is available for only six genera (larvae of Megasternum are known from older descriptions and therefore have not been included in this discussion). The sistergroup of Megasternini is the monotypic tribe Sphaeridiini (SHORT \& FIKÁČEK 2013), and this is also supported by larval characters. Nonetheless there are several differences between known larvae of Megasternini and Sphaeridium, suggesting that Sphaeridiini should be considered a well-supported tribe. Among these differences (not listed in Table 2) we can mention the presence of a short median projection in the nasale of Sphaeridium; the presence of seta AN9 (absent in Megasternini); SE1 very short (long in Megasternini); prementum ring-like, completely sclerotized (mostly unsclerotized in Megasternini); abdominal segment VIII with lateral fleshy projections (absent in Megasternini). What is still needed is to improve our knowledge of immatures of Megasternini, since only a handful of genera have described larvae (about 12\%); this can also be said for the other tribes of Sphaeridiinae, as larvae provide many morphological and chaetotaxic characters of phylogenetic importance.

\section{Acknowledgements}

CONICET (Consejo Nacional de Investigaciones Científicas y Tecnológicas, Argentina) is acknowledged for supporting systematic research. I want to thank Y. Minoshima and M. Fikáček for sharing information on Armostus and Motonerus larvae, and also for their critical review of the manuscript. P. W. Kovarik is acknowledged for his help in fieldwork and collecting. This is contribution number 143 from LIESA.

\section{References}

ARCHANGELSKY M. 1994: Description of the preimaginal stages of Dactylosternum cacti (Coleoptera: Hydrophilidae: Sphaeridiinae). Entomologica Scandinavica 25: 121-128.

ARCHANGELSKY M. 1997: Studies on the biology, ecology, and systematics of the immature stages of New World Hydrophiloidea (Coleoptera: Staphyliniformia). Bulletin of the Ohio Biological Survey, New Series 12: 1-207.

ARCHANGELSKY M. 1999a: Adaptations of immature stages of Sphaeridiinae (Staphyliniformia, Hydrophiloidea, Hydrophilidae) and state of knowledge of preimaginal Hydrophilidae. Coleopterists Bulletin 53: 64-79.

ARCHANGELSKY M. 1999b: Immature stages of Paracymus rufocinctus Bruch, 1915 and Enochrus (Methydrus) vulgaris (Steinheil, 1869) (Coleoptera: Hydrophilidae: Hydrophilinae). Elytron 13: 87-99.

ARCHANGELSKY M. 2016: Chaetotaxy and larval morphometry of Cercyon praetextatus (Say) and C. quisquilius (Linnaeus) (Coleoptera: Hydrophilidae: Sphaeridiinae) and their phylogenetic implications. Arthropod Systematics and Phylogeny 74: 177-193.

ARCHANGELSKY M., RODRIGUEZ G. \& TORRES P. L. M: 2016. Primary chaetotaxy and larval morphometry of Phaenonotum exstriatum and Dactylosternum cacti (Coleoptera: Hydrophilidae). Acta Entomologica Musei Nationalis Pragae 56: 167-193.

BLOOM D. D., FIKÁC̆EK M. \& SHORT A. E. Z. 2014: Clade age and diversification rate variation explain disparity in species richness among water scavenger beetle (Hydrophilidae) lineages. PLOS ONE 9(2)(e98430): 1-9.

BÖVING A. G. \& HENRIKSEN K. L. 1938: The developmental stages of the Danish Hydrophilidae. Videnskabelige Meddelelser Dansk Naturhistorisk Forening 102: 27-162.

BYTTEBIER B. \& TORRES P. L. M. 2009: Description of the preimaginal stages of Enochrus (Hugoscottia) variegatus (Steinheil, 1869) and E. (Methydrus) vulgaris (Steinheil, 1869) (Coleoptera: Hydrophilidae), with emphasis on larval morphometry and chaetotaxy. Zootaxa 2139: 1-22.

DELER-HERNÁNDEZ A., CALA-RIQUELME F. \& FIKÁČEK M. 2014: A review of the genus Oosternum Sharp of the West Indies (Coleoptera: Hydrophilidae: Sphaeridiinae). Deutsche Entomologische Zeitschrift 61: 43-63.

FIKÁC̆EK M. 2006: Primary chaetotaxy of the larval head of the hydrophiloid beetles (Coleoptera: Hydrophiloidea). Unpublished M.Sc. thesis, Department of Zoology, Faculty of Science, Charles University in Prague, Praha, 156 pp.

FIKÁČEK M., ARCHANGELSKY M. \& TORRES P. L. M. 2008: Primary chaetotaxy of the larval head capsule and head appendages of the Hydrophilidae (Coleoptera) based on larva of Hydrobius fuscipes (Linnaeus, 1758). Zootaxa 1874: 16-34.

FIKÁČEK M., GUSTAFSON G. T. \& SHORT A. E. Z. 2017: On wet rocks with snorkels: immature stages of Tritonus cascade beetles with unusual modification of spiracles (Coleoptera: Hydrophilidae: Laccobiini). Annales Zoologici 67: 91-107.

FIKÁČEK M., MINOSHIMA Y. N. \& NEWTON A. F. 2014: A review of Andotypus and Austrotypus gen. nov., rygmodine genera with an austral disjunction (Hydrophilidae: Rygmodinae). Annales Zoologici 64: 557-596.

FIKÁČEK M., MINOSHIMA Y. N., VONDRÁČEK D., GUNTER N. \& LESCHEN R. A. B. 2013: Morphology of adults and larvae and integrative taxonomy of southern hemisphere genera Tormus and 
Afrotormus (Coleoptera: Hydrophilidae). Acta Entomologica Musei Nationalis Pragae 53: 75-126.

FUHRMANN J., BENÁ D. D. C. \& CLARKSON B. 2013: Description of the last larval instar of Pelosoma (Hydrophilidae: Sphaeridiinae) from Brazil. Acta Entomologica Musei Nationalis Pragae 53: 899-900.

HADLEY A. 2010: CombineZP. Available from: http://www.hadleyweb. pwp.blueyonder.co.uk.

HAFEZ H. 1939: The external morphology of the full grown larva of Cercyon quisquilius L. (Hydrophilidae). Bulletin de la Société Fouad Ier d'Entomology 23: 339-343.

MINOSHIMA Y. N. in press: Larval morphology of Armostus ohyamatensis Hoshina \& Satô (Coleoptera: Hydrophilidae: Megasternini). Coleopterists Bulletin.

MINOSHIMA Y. \& HAYASHI M. 2011: Larval morphology of the Japanese species of the tribes Acidocerini, Hydrobiusini and Hydrophilini (Coleoptera: Hydrophilidae). Acta Entomologica Musei Nationalis Pragae 51 (supplementum): 1-118.

MINOSHIMA Y. \& HAYASHI M. 2012: Larval morphology of Amphiops mater mater Sharp (Coleoptera: Hydrophilidae: Chaetarthriini). Zootaxa 3351: 47-59.

MINOSHIMA Y. N., IWATA Y., FIKAČEK M. \& HAYASHI M. 2017 Description of immature stages of Laccobius (Laccobius) kunashiricus, with a key to genera of the Laccobiini based on larval characters (Coleoptera, Hydrophilidae). Acta Entomologica Musei Nationalis Pragae 57: 97-119.

MINOSHIMA Y. N., SEIDEL M., WOOD J. R., LESCHEN R. A. B., GUNTER N. L. \& FIKÁČEK M. 2018: Morphology and biology of flower-visiting water scavenger beetle genus Rygmodus (Coleoptera, Hydrophilidae). Entomological Science 21: 363-384
PHILLIPS K. C. J. 1923: The larva of a hydrophilid beetle Megasternum boletophagum. Irish Naturalist (Dublin) 32: 109-112.

PRINS A. J. 1984: Morphological and bionomical notes on some South African arthropods associated with decaying organic matter. Part 2. The predatory families Carabidae, Hydrophilidae, Histeridae, Staphylinidae and Silphidae (Coleoptera). Annals of the South African Museum 92: 295-356.

QUENNEDEY A. 1965: Contribution à la connaissance de quelques types larvaires de Sphaeridiinae (Col., Hydrophilidae). Travaux du Laboratoire de Zoologie et de la Station Aquicole Grimaldi (Dijon) 66: $1-56+41$ figures.

SCHULTE F. 1985: Eidonomy, ethoecology and larval systematics of dung-inhabiting Cercyon species (Coleoptera: Hydrophilidae). Entomologia Geneneralis 11: 47-55.

SHORT A. E. Z. \& FIKÁČEK M. 2011: World catalogue of the Hydrophiloidea (Coleoptera): additions and corrections II (2006-2010). Acta Entomologica Musei Nationalis Pragae 51: 83-122.

SHORT A. E. Z. \& FIKÁČEK M. 2013: Molecular phylogeny, evolution and classification of the Hydrophilidae (Coleoptera). Systematic Entomology 38: 723-752.

SMETANAA. 1978: Revision of the subfamily Sphaeridiinae of America north of Mexico (Coleoptera: Hydrophilidae). Memoirs of the Entomological Society of Canada 105: 1-292.

TORRES P. L. M., MICHAT M. C., ARCHANGELSKY M. \& FERNÁNDEZ L. A. 2014: Description of immatures of the genus Tropisternus Solier, subgenus Pristoternus Orchymont (Coleoptera: Hydrophilidae), with emphasis on the chaetotaxy and morphometry of larval forms. Zootaxa 3790: 380-398. 
